\title{
STUDIES ON THE NATURE OF PLASMIDS ARISING FROM CONJUGATION IN THE HUMAN GASTRO-INTESTINAL TRACT
}

\author{
J. D. Anderson, L. C. Ingram, M. H. Richmond and B. WiedemanN* \\ Department of Bacteriology, University of Bristol, University Walk, Bristol BS8 1TD
}

IN the studies described in the preceding paper (Anderson, Gillespie and Richmond, 1973), four persons were first fed with genetically marked strains of Escherichia coli to supplement their endogenous flora and to act as a potential and easily identifiable plasmid recipient. Another strain of $E$. coli containing a known $\mathrm{R}$ factor and also marked genetically for identification was then fed, but no organisms that might have arisen by $R$-factor transfer either to the existing enteric flora or to the "marked" potential recipient were isolated from the faeces of any of the subjects. However, when the experiment was repeated with three persons who were subsequently given a short course of treatment with an appropriate antibiotic, large numbers of organisms were isolated from the faeces that could have arisen by R-factor transfer to resident commensal $E$. coli strains (in two subjects) or to the "marked" ingested strain.

Claims that $\mathrm{R}$-factor transfer has occurred in vivo have relied almost entirely on a small chosen range of antibiotic-resistance determinants to identify plasmids in donor and recipient organisms. For reasons outlined in the preceding paper, the identification of only four or five gene products from an $\mathbf{R}$ factor containing enough DNA to specify at least ten times this number of genes is quite inadequate, particularly because different plasmids can determine resistance to the same antibiotic by the synthesis of different enzymes (Richmond and Sykes, 1973). To be reasonably certain that two plasmids are "the same", it is necessary to determine the biochemical basis of the resistance traits carried, the molecular weight, the transfer and compatibility properties of the plasmids, and to compare the isolated elements with one another by DNA/DNA hybridisation techniques.

The rigorous identification of plasmids in ingested and faecal organisms from the three persons studied in the previous paper (Anderson $e t$ al.) would be impracticable. Organisms from one person (E) were therefore chosen for further detailed examination. A selection of relevant isolates of ingested and faecal $E$. coli from this person were first identified serologically. Quantitative tests for antibiotic-resistance determinants were extended to include estimations of minimum inhibitory concentrations in order to identify more closely the $\mathbf{R}$ factors and the organisms in which they were present. As a final and crucial stage in plasmid identification, DNA/DNA hybridisation was carried out on a small selection of relevant plasmids whose molecular weights were also determined.

Received 30 Jan. 1973 ; accepted 14 Feb. 1973.

* Present address: Hygiene Institut, 6000 Frankfurt/Main, Paul Ehrlich Strasse 40, West Germany. J. MED. MiCROBIOL.-VOL. 6 (1973) 


\section{METHODS \\ Media}

Minimum inhibitory concentrations of antibiotics were determined on DST Agar (Oxoid Limited, London S.E.1), pH 7·4, supplemented with saponin-lysed oxalated horse-blood (5 per cent.). Antibiotics were incorporated into this medium by the addition of appropriate amounts of proprietory sterile parenteral preparations of ampicillin, kanamycin, streptomycin, sulphadimidine, or tetracycline. The $p \mathrm{H}$ of media containing large amounts of sulphadimidine had to be corrected with $\mathrm{N}$ hydrochloric acid and those containing high concentrations of kanamycin and tetracycline with $\mathrm{N}$ sodium hydroxide. Chloramphenicol B.P. was dissolved in water or dimethylsulphoxide for the preparation of media containing this antibiotic.

For R-factor-transfer studies MacConkey bile-lactose agar was prepared with or without antibiotics as already described (Anderson et al.).

Media and materials for molecular studies have been described by Ingram et al. (1972) and Grinsted et al. (1972). Cultures were generally grown on a liquid minimal medium supplemented with DL-methionine ( $40 \mu \mathrm{g}$ per $\mathrm{ml})$, $\mathrm{L}$-leucine $(20 \mu \mathrm{g}$ per $\mathrm{ml})$ and thymine $(2 \mu \mathrm{g}$ per $\mathrm{ml})$. The thymine content of the medium was reduced to $1 \mu \mathrm{g}$ per $\mathrm{ml}$ for radiochemical incorporation experiments.

\section{Buffer solutions}

Double-strength saline-citrate buffer, $p \mathrm{H} 7 \cdot 0$, contained $0.30 \mathrm{M}$ sodium chloride and

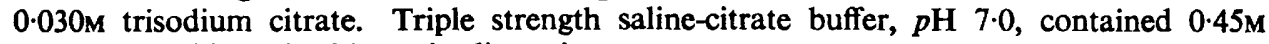
sodium chloride and $0.045 \mathrm{M}$ trisodium citrate.

\section{Organisms}

The biochemical identification and the qualitative antibiotic-resistance patterns of strains of $E$. coli ingested by, or recovered from, a single subject (E) have already been described (Anderson et al.). $\mathrm{R}$ factors were transferred from some of these isolates into a nalidixic-acidresistant laboratory strain (NAR) of E. coli, as previously described. The antibiotic-resistance patterns of $R$ factors present in various isolates could then be quantitatively compared in a common organism.

E. coli, strain NC22 (a spontaneous mutant of NC21, Ingram et al. 1972), which is resistant to both nalidixic acid and rifampicin, was used for hybridisation studies because it is known to be free from extraneous plasmid DNA.

\section{Quantitative determination of antibiotic sensitivities}

The sensitivity of E. coli strains to a range of antibiotics was determined at approximately two-fold steps of antibiotic concentration on lysed-blood-agar incorporation plates. "Single colony" antibiotic-inhibitory concentrations were conveniently determined by a multipleinoculation technique in which $0.001-\mathrm{ml}$ portions of suspensions of a range of bacterial cell densities could be applied to each plate.

\section{Identification of $\beta$-lactamases}

The serological method with specific antisera described by Datta and Richmond (1966) was employed.

\section{Determination of rates of $R$-factor transfer in laboratory media}

Overnight broth cultures of organisms, containing between $2 \times 10^{9}$ and $10 \times 10^{9}$ viable organisms per $\mathrm{ml}$ were centrifuged at $1500 \mathrm{~g}$ for $20 \mathrm{~min}$., then suspended in fresh broth. Suspensions containing about $10^{7}$ organisms per $\mathrm{ml}$ of the potential donor and $5 \times 10^{7}$ organisms per ml of the potential recipient were incubated in broth at $37^{\circ} \mathrm{C}$. Viable counts of potential donor and recipient organisms were determined at hourly intervals on antibioticincorporation plates and a portion $(0.005 \mathrm{ml}$ from a standardised wire loop) of culture was 
streaked on to antibiotic-incorporation plates that would select for organisms resulting from $\mathrm{R}$-factor transfer. Transfer frequencies were usually calculated from changes observed in the numbers of transcipients between the ist and 2nd, or between the 2nd and 3rd, hours of contact. Organisms containing $\mathbf{R}$ factors that transferred at exceptionally low frequency (in practice, $<10^{-7}$ per donor) were incubated overnight with a recipient, then concentrated by centrifugation, and a thick suspension containing c. $10^{10}$ organisms was spread over suitable antibiotic-incorporation plates.

\section{Serological typing of Escherichia coli isolates}

The methods of Wiedemann et al. (1971) were used, and $O$ antigens determined by a tubeagglutination technique modified for use in the Cooke Microtiter Apparatus (Cooke Engineering Co., Alexandria, Virginia, USA). Suitable rabbit antisera wore prepared against standard strains of $E$. coli obtained from the WHO Escherichia Centre, Copenhagen, Denmark. Some isolates proved to be autoagglutinable and therefore could not be typed by this method.

\section{Isolation of plasmid DNA}

Overnight cultures of $E$. coli in supplemented minimal liquid medium were diluted with fresh medium (final volume $10 \mathrm{ml}$ ) and incubated at $37^{\circ} \mathrm{C}$ until a culture was obtained with an optical density of 0.05 at $675 \mathrm{~nm}$. Growth was allowed to continue for a further three hr after the addition of either ${ }^{3} \mathrm{H}$-thymine $(100 \mu \mathrm{Ci})$ or ${ }^{14} \mathrm{C}$-thymine $(20 \mu \mathrm{Ci})$ to the culture. Lysates $(1.25 \mathrm{ml})$ of the organisms were then propared as described by Grinsted et al., and mixed with caesium chloride $(5.58 \mathrm{~g})$, ethidium bromide $(2.8 \mathrm{mg}$ in $2 \mathrm{ml}$ of $0.1 \mathrm{M}$ phosphate

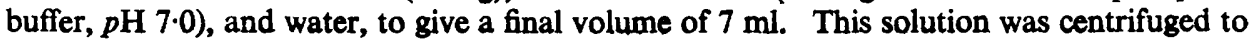
equilibrium in the $10 \times 10 \mathrm{ml}$ angle rotor of an MSE "Superspeed 50 " centrifuge for $40 \mathrm{hr}$ at 42,000 r.p.m. The resulting caesium chloride gradients were fractionated into about 40 equal samples, and the radiotracer content of a $20-\mu \mathrm{l}$ sample of each fraction estimated by liquid scintillation counting.

\section{DNA/DNA hybridisation}

Bacterial DNA was prepared from batches $(500 \mathrm{ml})$ of overnight cultures by the method of Marmur (1961). Traces of RNA in the DNA preparations were removed by incubation at $37^{\circ} \mathrm{C}$ for $30 \mathrm{~min}$. with ribonuclease $\mathrm{A}(50 \mu \mathrm{g}$ per $\mathrm{ml}$; Sigma Chemical Co., Kingston-uponThames, Surrey) and ribonuclease $T_{1}$ (200 units per ml; Sigma Chemical Co.). The bacterial DNA solutions were denatured by the addition of sodium hydroxide to a final concentration of $0.3 \mathrm{M}$ followed by incubation at $37^{\circ} \mathrm{C}$ for $15 \mathrm{~min}$. The solutions were then neutralised with hydrochloric acid and samples of $20 \mu \mathrm{l}$ fixed to nitrocellulose filters by the method of Denhardt (1966).

Two radiolabelled preparations of covalently closed circular (CCC) R-factor DNA, one containing ${ }^{3} \mathrm{H}$, and the other ${ }^{14} \mathrm{C}$, equal to an observed radiotracer content of $10^{4}$ to $10^{5}$ c.p.m., were used for each hybridisation experiment. The two preparations were combined, calf-thymus DNA (50 $\mu \mathrm{g}$, Sigma Chemical Co.) was added to reduce non-specific reactions and the volume made up to $0.5 \mathrm{ml}$ with a final ionic strength equivalent to triple-strength saline-culture buffer. The mixture of DNA was fragmented in solution by exposure to ultrasound (Dawe Ultrasonic Disintegrator, Dawe Instruments Ltd., Beckenham, Kent), for $30 \mathrm{sec}$. at an output of $2 \mathrm{~A}$ and $25,000 \mathrm{~Hz}$ and then denatured by heating to $95^{\circ} \mathrm{C}$ for $10 \mathrm{~min}$.

The mixture of denatured DNA was allowed to bind to a filter preloaded with DNA from the $\mathrm{R}^{+}$derivative of $E$. coli strain NC22 corresponding to one of the two radiolabelled plasmids. A second filter, containing DNA from the NC22 $\mathrm{R}^{-}$parent, was included in the reaction vial as a control to measure non-specific binding. After incubation at $65^{\circ} \mathrm{C}$ for $16 \mathrm{hr}$, the filters were removed and washed, and the bound radioactivity was determined (Ingram et al.). Results are expressed as the percentage binding of the non-homologous R-factor DNA after correction for binding of the appropriate homologous $\mathbf{R}$-factor nucleic acid.

J. MED. MICROBIOL.-VOL. 6 (1973) 


\section{RESULTS}

\section{Serological characteristics of the isolates}

Subject $E$ was first fed with a nalidixic-acid-resistant strain of $E$. coli, which had been prepared by mutation of a strain isolated from his own faecal flora (Anderson et al.). The nalidixic-acid-resistant strain was of serotype 02 , and $E$. coli strains of this serotype but nalidixic-acid sensitive were therefore likely to have been present in the gut of subject $\mathrm{E}$ before the experiments began.

Subject $E$ was then fed with a rifampicin-resistant mutant strain of $E$. coli carrying the plasmid $R-1$, followed by a course of ampicillin (see the previous paper). The plasmid $\mathrm{R}-1$ determined resistance to ampicillin (A), chloramphenicol (C), kanamycin (K), streptomycin (S), and sulphonamides (Su). Both the ingested organisms and the strains with the same resistance pattern (ACKSSu) isolated subsequently from faeces were autoagglutinable. Autoagglutinability was a moderately good index of strain identity in this series of experiments, because none of the 43 strains of $E$. coli with different marker patterns isolated from subject $E$ possessed this property.

Strains of $E$. coli containing the resistance determinants characteristic of R-1 (ACKSSu), but sensitive to rifampicin and to nalidixic acid, were isolated from subject $E$ on 16 occasions over a period of 27 days. Fourteen of these sixteen isolates were serotyped and found to be of serotype $\mathrm{O} 2$. They were therefore unlikely to have arisen by spontaneous loss of rifampicin resistance from the autoagglutinable ingested strain. They may, however, have arisen by R-factor transfer of R-1 to the $E$. coli serotype-O2 strains present in the bowel before the beginning of the experiment.

Small numbers of a strain of $E$. coli resistant to tetracycline (T) as well as the markers characteristic of $\mathrm{R}-1$, but sensitive to rifampicin and to nalidixic acid, were isolated from subject $E$ on two occasions 5 and 8 days after ingestion of the R-1-carrying donor strain (see table IV of the preceding paper). Both these isolates were serotyped and found to be of type O9. This multi-resistant strain may therefore have arisen by transfer of $\mathrm{R}-1$ to a resident organism of type 09 already resistant to tetracycline.

Two other resistant $E$. coli strains were present in subject $\mathrm{E}$ during the course of the experiment. The first was of serotype O9 but had the marker pattern AST. This strain may be the one that acted as recipient to R-1 and thereafter expressed the markers characteristic of R-1 (ACKSSu) together with tetracycline resistance. The other was a strain of serotype 015 that had the marker pattern, SSuT. This strain does not seem to have been involved as a recipient for R-1 transfer during the course of these experiments.

\section{Detailed studies on antibiotic-resistance patterns}

The results summarised in table I show that the quantitative antibioticresistance patterns of all the isolates of the ACKSSu $E$. coli strains of serotype O2 were identical within experimental limits (table I, row 3). Moreover, the resistance patterns shown by these strains were indistinguishable from the pattern of the autoagglutinable strain carrying R- 1 that was fed as a potential donor 
(compare rows 2 and 3 , table $I$ ). The minimum inhibitory concentration values for the ACKSSuT isolates of E. coli type 09, and for the AST-resistant isolate of this serotype (c.f. rows 4 and 5, table I) are compatible with the possibility, which had been suggested by the serological findings, that the multi-resistant strains had arisen by transfer of R-1 to a resident type-09 strain expressing the markers AST. As well as displaying a high degree of resistance to tetracycline, the multi-resistant organisms were much more resistant to streptomycin, and marginally more resistant to ampicillin, than the tetracycline-resistant strains of type 09 also isolated from the gut of subject $\mathrm{E}$ (table $\mathrm{I}$ ).

TABLE I

Summary of single-colony minimum inhibitory concentration (MIC) values of a range of antibiotics for various strains of Escherichia coli obtained from subject $E$.

\begin{tabular}{|c|c|c|c|c|c|c|}
\hline \multirow[b]{2}{*}{ Description of $E$. coli strains } & \multicolumn{6}{|c|}{$\mathrm{MIC}(\mu \mathrm{g}$ per $\mathrm{ml})$ of } \\
\hline & $\begin{array}{l}\text { ampi- } \\
\text { cillin }\end{array}$ & $\begin{array}{l}\text { chloram- } \\
\text { phenicol }\end{array}$ & $\begin{array}{l}\text { kana- } \\
\text { mycin }\end{array}$ & $\begin{array}{l}\text { strepto- } \\
\text { mycin }\end{array}$ & $\begin{array}{l}\text { sulpha- } \\
\text { dimidine }\end{array}$ & $\begin{array}{l}\text { tetra- } \\
\text { cycline }\end{array}$ \\
\hline $\begin{array}{l}\text { Nalidixic-acid resistant deriv- } \\
\text { ative of type } \mathrm{O} 2 \text { (the poten- } \\
\text { tial recipient) }\end{array}$ & 4 & 2 & 0.5 & 1 & 32 & 1 \\
\hline $\begin{array}{l}\text { Autoagglutinable strains car- } \\
\text { rying } R-1 \text { (the potential } \\
\text { donor) }\end{array}$ & 512 & 512 & 1024 & 16 to 32 & $\begin{array}{l}8000 \text { to } \\
16000\end{array}$ & 1 \\
\hline $\begin{array}{l}\text { A selection of } 14 \text { of } 16 \text { isolates } \\
\text { of type } O 2 \text { obtained from } \\
\text { the faeces of subject } E \text { be- } \\
\text { tween day } 5 \text { and day } 32\end{array}$ & 256 to 512 & 512 & 512 to 1024 & 32 & 8000 & 1 \\
\hline $\begin{array}{l}\text { Type-09 strains, AST resist- } \\
\text { ant }\end{array}$ & 256 & 4 & 2 to 4 & 128 & 64 & 256 \\
\hline $\begin{array}{l}\text { Type-09 strains, ACKSSuT } \\
\text { resistant }\end{array}$ & 1024 & 512 & 512 & 128 & 16000 & 256 \\
\hline
\end{tabular}

See text for key to antibiotic abbreviations.

$\mathbf{R}$ factors were transferred in laboratory experiments to a common, known recipient $E$. coli strain both from the autoagglutinable strain carrying R-1 and also from one of the multi-resistant isolates of serotype $\mathrm{O} 2$ that may have arisen by transfer. Both the $\mathbf{R}$ factors expressed identical levels of resistance in this laboratory recipient (table II), and this provides further evidence that the plasmid isolated in the ACKSSu-resistant strains of $E$. coli type $\mathrm{O} 2$ was similar to the plasmid R-1 fed originally in the autoagglutinable strain.

None of the 19 samples of faeces taken from subject $\mathrm{E}$ before the feeding experiments (and incidentally from the other four subjects also described in the preceding paper) contained detectable bacterial populations resistant to chloramphenicol and none contained organisms with more than four antibiotic-resistance determinants. The isolation of the $E$. coli type- $\mathrm{O} 2$ strains expressing resistance to five antibiotics including chloramphenicol is therefore further circumstantial evidence that transfer of R-1 to the $E$. coli type-O2 strains resident in the gut may have occurred in subject $\mathrm{E}$. 
The plasmid R-1 specifies type-IIIa $\beta$-lactamase, and a specific neutralising antiserum for this enzyme is available (Datta and Richmond). The $\beta$-lactamase expressed by the autoagglutinable $E$. coli strain carrying R-1, and by isolates of the ACKSSu-resistant $E$. coli type $\mathrm{O}$, reacted identically with the specific antitype-IIIa $\beta$-lactamase serum. The ACKSSuT- and AST-resistant type-O9 strains also synthesised type-IIIa $\beta$-lactamase.

The transfer frequency of the ingested autoagglutinable donor strain of $E$. coli containing R-1 (ACKSSu) was about $3 \times 10^{-3}$ per donor organism per $\mathrm{hr}$. Because the transfer frequencies of the multi-resistant ACKSSuT strain O9 and

TABLE II

Single-colony minimum inhibitory concentration (MIC) values obtained on transfer of $R$ factors from the ACKSSu-resistant autoagglutinable Escherichia coli strain and from the ACKSSUresistant type-O2 $E$. coli strain to a laboratory strain, $E$. coli $(N A R)$ that was sensitive to three antibiotics

\begin{tabular}{l|cccccc}
\hline Description of $E$. coli strains & \multicolumn{5}{|c}{ MIC ( $\mu \mathrm{g}$ per ml) for } \\
\hline $\begin{array}{c}\text { ampi- } \\
\text { cillin }\end{array}$ & $\begin{array}{c}\text { chloram- } \\
\text { phenicol }\end{array}$ & $\begin{array}{c}\text { kana- } \\
\text { mycin }\end{array}$ & $\begin{array}{c}\text { strepto- } \\
\text { mycin }\end{array}$ & $\begin{array}{c}\text { sulpha- } \\
\text { dimidine }\end{array}$ \\
\hline $\begin{array}{c}\text { Strain NAR carrying the R factor from } \\
\text { the autoagglutinable donor } \\
\begin{array}{c}\text { Strain NAR carrying the R factor from } \\
\text { the type-O2 donor }\end{array}\end{array}$ & 256 & 512 & 512 & 8 & 2000 \\
\hline
\end{tabular}

See text for key to antibiotic abbreviations.

the AST serotype 09 were scarcely measurable (less than $5 \times 10^{-10}$ per donor organism during overnight incubation), all the ACKSSuT resistance determinants perhaps use the apparently inefficient transfer-determining genes of the AST plasmid rather than those of R-1.

\section{Molecular studies on plasmids}

Four selected $\mathrm{R}$ factors were transferred from the parent strains to $E$. coli strain NC22 for molecular studies, because this recipient is known to be free of extraneous plasmid DNA (Ingram et al.). The donor strains chosen for this purpose were the autoagglutinable strain carrying R-1 (ACKSSu), which was used as the potential donor in these experiments, two isolates of the ACKSSuresistant $E$. coli type $\mathrm{O} 2$ isolated on days 13 and 27 of the experiment, and one isolate of the ACKSSuT-resistant E. coli type-O9 strain obtained on the eighth day of the experiment. The recipients obtained from these donors have been designated strains $A$ to $D$ in the following experiments, and the transfer frequencies obtained with these donors are summarised in table III. Whereas the autoagglutinable and type-O2 donors transferred a plasmid with the marker pattern ACKSSu, the type-O9 strain always gave linked transfer of ACKSSuT. This observation suggests that the ACKSSuT pattern in the type-O9 strains may have arisen by recombination between R-1 and another plasmid conferring 
resistance to tetracycline, and already resident in a type-O9 $E$. coli strain in the gut of subject $\mathrm{E}$.

CCC forms of plasmid DNA may be separated from chromosomal DNA by centrifugation in $\mathrm{CsCl}$ gradients containing ethidium bromide (Radloff, Bauer and Vinograd, 1967). Lysates of the plasmid-bearing $E$. coli strain A were grown in ${ }^{14} \mathrm{C}$-thymine, and all other strains in ${ }^{3} \mathrm{H}$-thymine, for analysis by $\mathrm{CsCl} /$ ethidium bromide centrifugation. The ACKSSu- and ACKSSuT-resistant derivatives of

TABLE III

Properties of R-factor-bearing strains of Escherichia coli chosen for molecular studies

\begin{tabular}{c|ccc}
\hline Origin of organism & $\begin{array}{c}\text { Resistance } \\
\text { doterminants } \\
\text { transferred to } E \text {. coli } \\
\text { NC 22* }\end{array}$ & $\begin{array}{c}\text { Transfer frequency } \\
\text { in a laboratory } \\
\text { medium } \\
\text { (per donor organism) }\end{array}$ & $\begin{array}{c}\text { Laboratory } \\
\text { designation } \\
\text { of R-factor-bearing } \\
\text { strains of } E \text {. coli } \\
\text { NC 22 }\end{array}$ \\
\hline $\begin{array}{c}\text { Autoagglutinable strain con- } \\
\text { taining R-1 that was fed to } \\
\text { subject E }\end{array}$ & ACKSSu \\
$\begin{array}{c}\text { Strain of ACKSSu-resistant } \\
\text { serotype O2 isolated from } \\
\text { faeces on day 13 of experi- } \\
\text { ment }\end{array}$ & ACKSSu \\
$\begin{array}{c}\text { Strain of ACKSSu-resistant } \\
\text { serotype O2 isolated from } \\
\text { faeces on day 27 of experi- } \\
\text { ment }\end{array}$ & ACKSSu \\
$\begin{array}{c}\text { Strain of ACKSSuT-resistant } \\
\text { serotype O9 isolated from } \\
\text { faeces on day } 8 \text { of experi- } \\
\text { ment }\end{array}$ & ACKSSuT & $\begin{array}{c}\text { approximately } \\
3 \times 10^{-3} \\
\text { per hour }\end{array}$ & Strain B \\
\hline
\end{tabular}

* See text for key to antibiotic abbreviations. In every case all resistance determinants transferred in toto to strain NC 22.

E. coli NC22 (strains A to D) all gave small satellite peaks of ${ }^{3} \mathrm{H}$-containing material on the dense side of the main chromosomal peaks whereas the plasmidless parent did not (fig. 1).

The CCC-DNA preparations isolated from strains $\mathrm{B}, \mathrm{C}$ and $\mathrm{D}$ by $\mathrm{CsCl} /$ ethidium-bromide centrifugation were further analysed by velocity sedimentation through sucrose gradients to determine the molecular size of the plasmids. CCC-DNA from strain A, which was known to contain the plasmid R-1, acted as a standard. The sucrose gradients showed that each CCC-DNA preparation could be resolved into two components (fig. 2). This pattern is typical of CCC-DNA; the slower sedimenting peaks, which could be formed from the faster by treatment with small quantities of deoxyribonyclease, probably represent open circular forms of the plasmid DNA (Grinsted et al.).

The CCC-DNA preparations from strains. B and C, which contained the resistance determinants of $\mathrm{R}-1$, both sedimented at the same rate as that of strain A, which was known to contain plasmid R-1. By contrast, the CCC-DNA from strain $D$, which contained the resistance determinants for tetracycline as 

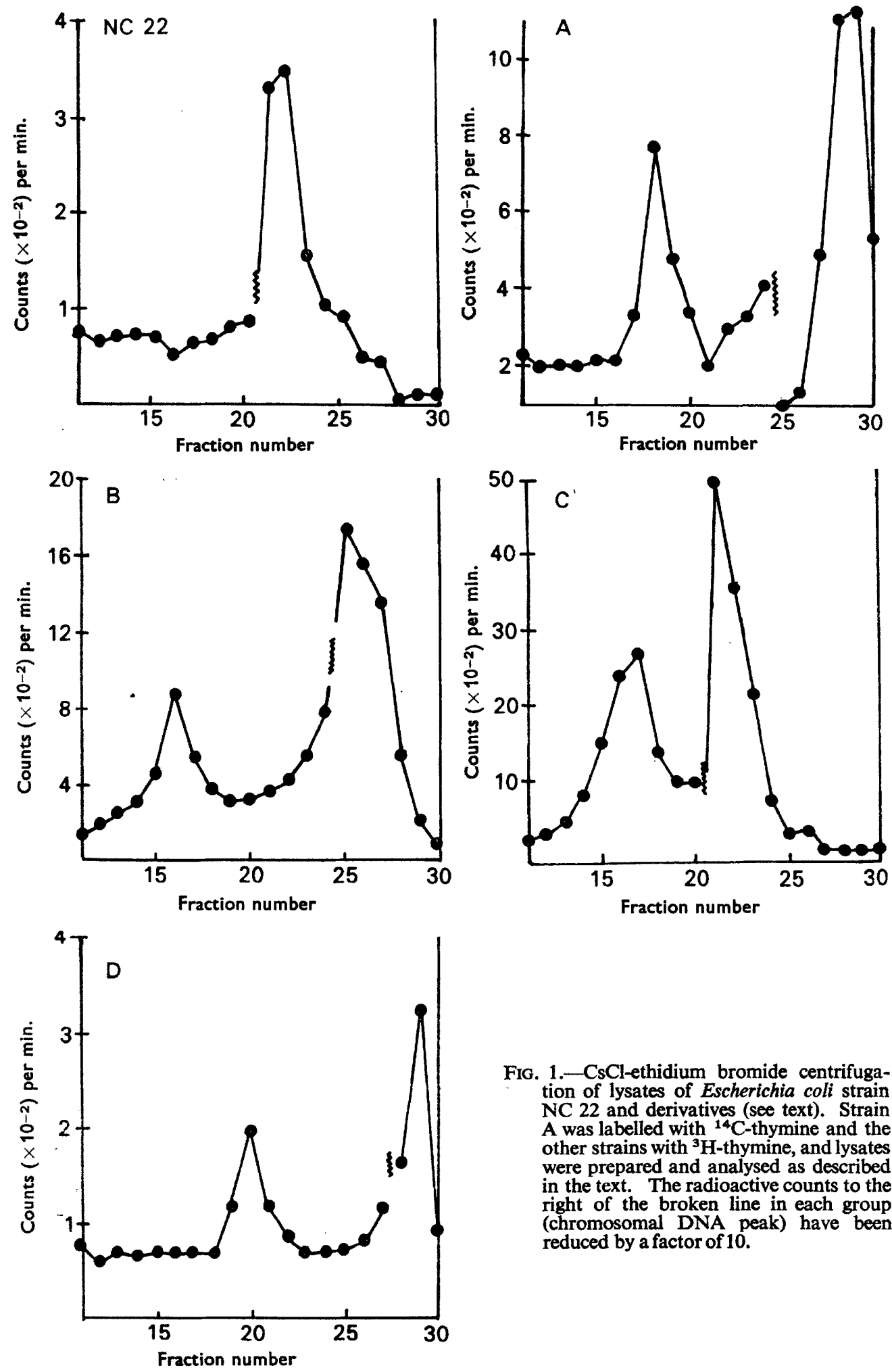

Fig. 1.- $\mathrm{CsCl}$-ethidium bromide centrifugation of lysates of Escherichia coli strain NC 22 and derivatives (see text). Strain A was labelled with ${ }^{14} \mathrm{C}$-thymine and the other strains with ${ }^{3} \mathrm{H}$-thymine, and lysates were prepared and analysed as described in the text. The radioactive counts to the right of the broken line in each group (chromosomal DNA peak) have been reduced by a factor of 10 . 
well as those of R-1, and which may well have been recombinant plasmid (see above) sedimented 1-16 times as fast as did R-1 (fig. 2 and table IV). Approximate molecular weights of the plasmid-DNA molecules were calculated by means of the relationship of Studier (1965) and the assumption that there is a proportionate increase in the sedimentation coefficient of CCC-DNA compared with linear DNA for similar plasmids. These calculations give a molecular weight
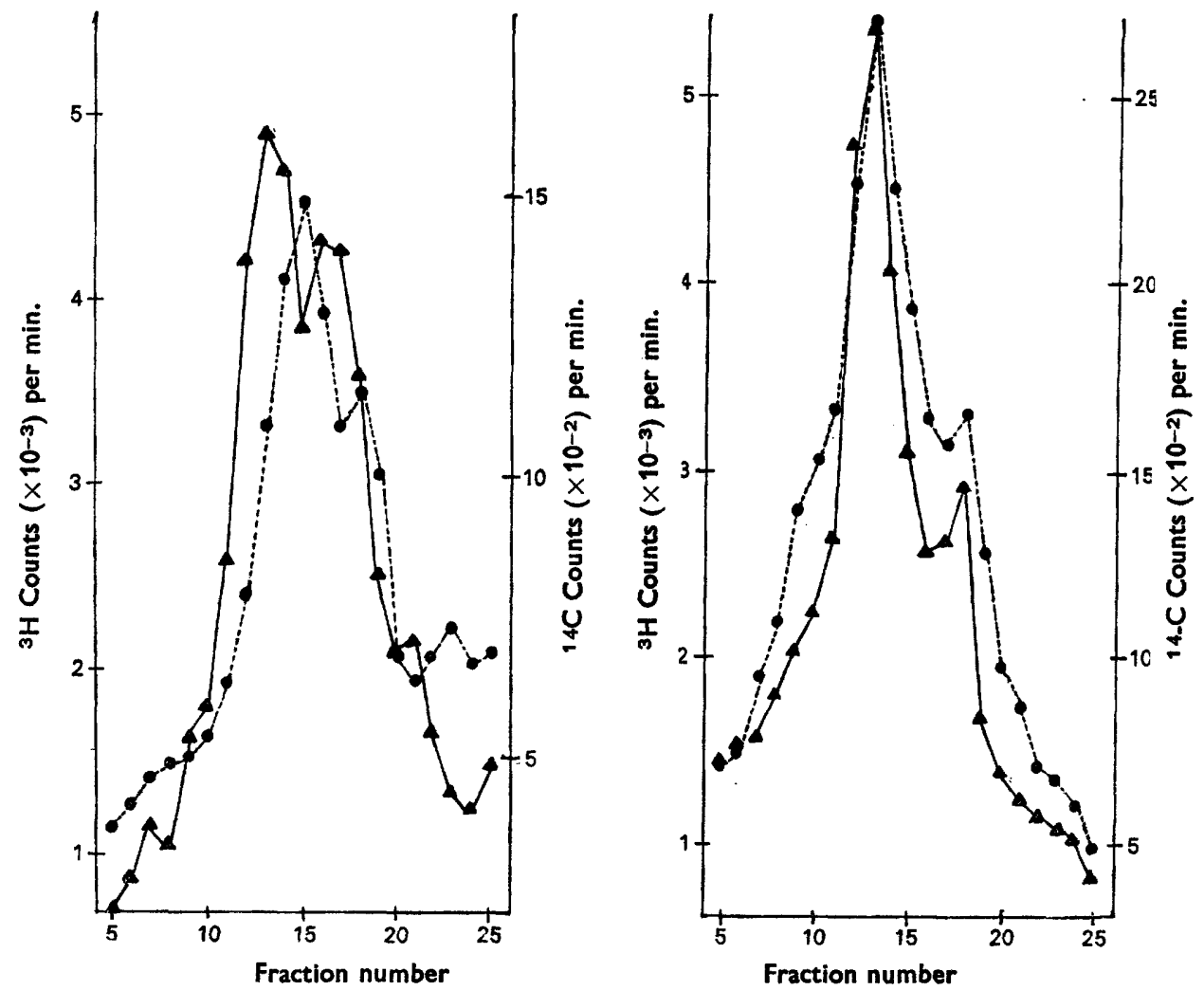

FIG. 2.-Sucrose gradient sedimentation of plasmid DNA. Left. ${ }^{14} \mathrm{C}$-labelled plasmid DNA from strain A cosedimented with ${ }^{3} \mathrm{H}$-labelled plasmid DNA from strain D. Right. ${ }^{14} \mathrm{C}$-labelled plasmid DNA from strain A cosedimented with ${ }^{3} \mathrm{H}$-labelled plasmid DNA from strain C.

of about $64 \times 10^{6}$ for the plasmids from strains $B$ and $C$, and of about $79 \times 10^{6}$ for the plasmid from strain $D$, on the assumption that the molecular weight of R-1 is $64 \times 10^{6}$ (Cohen and Miller, 1970).

DNA-sequence homology between R-1 and the plasmids in strains B, C and $D$ was measured by reciprocal hybridisation of pairs of plasmids with an excess of chromosomal DNA from $\mathrm{R}^{+}$strains. This was possible because control experiments showed that $\mathrm{R}^{-}$chromosomal DNA from $E$. coli $\mathrm{NC22}$ would bind with none $(<0.5$ per cent.) of the plasmid-DNA preparations. All the plasmid preparations from strains $B$ and $C$ bound to DNA from strain A whereas only 68 per cent. of the DNA from strain D did so (table V). The reciprocal test 
of the amount of plasmid DNA from strain A that could bind to the other three plasmids was approximately 100 per cent. in each case (table V). This observation, coupled with the larger size of the plasmid in strain $D$, suggests that most

TABLE IV

Sedimentation of plasmid DNA through sucrose gradients

\begin{tabular}{l|cc}
\hline \multicolumn{1}{c|}{ Source of plasmid* } & $\begin{array}{c}\text { Sedimentation } \\
\text { coefficient } \\
\text { relative to R-1 }\end{array}$ & $\begin{array}{c}\text { Molecular } \\
\text { weight† } \\
\times 10^{-6}\end{array}$ \\
\hline E. coli NC 22, strain A (known to contain R-1) & 1.0 & 64 \\
E. coli NC 22, strain B & 1.0 & 64 \\
$E$. coli NC 22, strain C & 1.0 & 64 \\
E. coli NC 22, strain D & 1.10 & 79 \\
\hline
\end{tabular}

- See text for origin of strains A to D.

$\uparrow$ Standard deviation of estimates $= \pm 6 \%$; molecular weights calculated as described in the text.

of the $64 \times 10^{6}$ daltons of DNA from R-1 is represented in the plasmid from strain D, but that the latter plasmid also contains about $25 \times 10^{6}$ daltons of DNA not represented in R-1. Because this larger plasmid confers resistance

TABLE V

Sequence homologies between $R-1$ and various plasmids detected in strains isolated from the faeces of subject $E$.

\begin{tabular}{|c|c|c|c|}
\hline Source of plasmid DNA & $\begin{array}{c}1 \\
\text { Percentage of plasmid } \\
\text { DNA homologous } \\
\text { with that isolated } \\
\text { from strain A }\end{array}$ & $\begin{array}{l}2 \\
\text { Percentage of plasmid } \\
\text { DNA from strain A } \\
\text { homologous with that } \\
\text { isolated from the } \\
\text { test organism }\end{array}$ & $\begin{array}{c}3 \\
\text { DNA homologous } \\
\text { with DNA from } \\
\text { strain A } \\
\text { (daltons } \times 10^{-6} \text { ) }\end{array}$ \\
\hline $\begin{array}{l}E . \text { coli NC 22, strain B } \\
E . \text { coli NC 22, strain C } \\
E \text {. coli NC } 22 \text {, strain D }\end{array}$ & $\begin{array}{l}98 \pm 5 \\
99 \pm 5 \\
68 \pm 5\end{array}$ & $\begin{array}{r}98 \pm 5 \\
99 \pm 5 \\
101 \pm 5\end{array}$ & $\begin{array}{l}63 \\
63 \\
54\end{array}$ \\
\hline
\end{tabular}

The values in columns 1 and 2 were measured as described in the text, and those in column 3 calculated from the data in columns 1 and 2, together with the molecular weight values (see text and table IV).

to tetracycline as well as carrying all the markers characteristic of R-1, it seems possible that the plasmid in strain $\mathrm{D}$ is a recombinant that arose following the feeding of R-1 in the autoagglutinable donor, and the results of the transfer experiments shown in table III are certainly consistent with this interpretation. The hybridisation data also show that the plasmids in strains $\mathrm{B}$ and $\mathrm{C}$ are indistinguishable from the R-1 plasmid originally fed in the autoagglutinable donor.

\section{Discussion}

As with all experiments that seek to show R-factor transfer in vivo, the crucial point to prove is that the resistant strain arose by transfer and not by selection 
of an organism already present in small numbers in the host. In the case of the ACKSSu-resistant type-O2 strains that appeared in subject $\mathrm{E}$, transfer seems certain. Not only did the plasmid in these strains have all the resistance markers characteristic of $\mathrm{R}-1$, it also had the same molecular weight and DNA sequence within the limits of experimental error.

Apart from the ACKSSu-resistant type-O2 strains that arose in subject E, an ACKSSuT-resistant type-O9 strain was present from time to time. The evidence suggests strongly that this arose by recombination of R-1 with another plasmid, possibly the AST plasmid already known to be present in some type-O9 strains in subject E. Not only was the ACKSSuT linkage-group transferred as a single unit by conjugation, but two-thirds of the plasmid had the same-or at least an extremely similar-sequence to R-1. What is less certain is that the remainder of this large plasmid was derived from the AST plasmid of the typeO9 strains. In order to confirm this origin, it would be necessary to discover whether the remaining third of the plasmid hybridised with all or part of the AST plasmid. Even in the absence of this clinching evidence, however, it seems certain that the ACKSSuT plasmid arose in the type-O9 strains by recombination.

The AST-resistant type-O9 organism appeared in the faeces in appreciable numbers only during and after ampicillin treatment. Thus the appearance of the ACKSSuT-resistant type-O9 organism is probably yet another consequence of chemotherapy. The multi-resistant ACKSSuT organism was detected only on two occasions and formed less than 0.0001 per cent. of the faecal aerobic Gram-negative bacteria. Although quantitatively unimportant in this experiment, this multi-resistant organism might have dominated the faecal flora if selection pressure had been applied by treatment with tetracycline. Sequential treatment with different antibiotics is not uncommon in clinical practice and hence may well be a factor leading to the emergence of highly resistant plasmids.

\section{SUMMARY}

In the studies described in the preceding paper, circumstantial evidence was found for transfer of antibiotic resistance from an ingested strain of Escherichia coli carrying an $\mathrm{R}$ factor, $\mathrm{R}-1$, which determined resistance to ampicillin (A), chloramphenicol (C), kanamycin (K), streptomycin (S) and sulphonamide (Su). Resistant organisms isolated from the faeces of a single individual were examined in detail to prove conclusively that the DNA of the ingested plasmid had transferred to other organisms.

The $O$ antigens of the resistant faecal isolates were the same as those of two organisms present before the beginning of the experiment, and these strains were resistant to all the determinants of $R-1$. The levels of resistance of the isolates to these antibiotics were quantitatively consistent with transfer of the plasmid $\mathrm{R}-1$; and the $\beta$-lactamase conferring ampicillin resistance was of the same antigenic type.

The predominant resistant organism isolated from the faeces transferred resistance to ACKSSu to laboratory recipients, and plasmid DNA isolated from such strains had the same molecular weight as R-1 and gave 100 per cent. DNA 
hybridisation with DNA from R-1. Small populations of another strain were also isolated which transferred resistance to ACKSSu and to tetracycline, and this plasmid contained all of the DNA base sequence of R-1 plus additional DNA. The serotype of this strain was the same as that of a strain already resistant to tetracycline before the beginning of the experiment.

These results prove that $\mathbf{R}$-factor transfer must have occurred during or after antibiotic therapy and illustrates possible dangers of chemotherapy.

We wish to thank Mrs H. M. Clements of the University of Bristol and Miss L. Ihrig of the Hygiene Institut, Frankfurt, for their excellent technical assistance, and Professor W. A. Gillespie for his interest.

This work was supported by a Programme Grant for molecular and epidemiological studies on $\mathbf{R}$ factors and other plasmids from the Medical Research Council to M. H. R., and by a Wellcome Anglo-German Exchange Fellowship to B. W.

\section{REFERENCES}

Anderson, J. D., Gillespie, W. A., AND Richmond, M. H. 1973. Chemotherapy and antibiotic-resistance transfer between Enterobacteria in the human gastro-intestinal tract. J. Med. Microbiol., 6, 461.

Cohen, S. N., AND Miller, Christine A. 1970. Non-chromosomal antibiotic resistance in bacteria. II. Molecular nature of R-factors isolated from Proteus mirabilis and Escherichia coli. J. Molec. Biol., 50, 671.

DatTa, NaOmi, and Richmond, M. H. 1966. The purification and properties of a penicillinase whose synthesis is mediated by an R-factor in Escherichia coli. Biochem. J., 98, 204.

Denhard, D. T. 1966. A membrane-filter technique for the detection of complementary DNA. Biochem. Biophys. Res. Commun., 23, 641.

Grinsted, J., Saunders, J. R., Ingram, L. C., Sykes, R. B., and Richmond, M. H. 1972. Properties of an $\mathrm{R}$ factor which originated in Pseudomonas aeruginosa 1822. J. Bact., 110, 529.

Ingram, L. C., Sykes, R. B., Grinsted, J., Saunders, J. R., And Richmond, M. H. 1972. A transmissable resistance element from a strain of Pseudomonas aeruginosa containing no detectable extrachromosomal DNA. J. Gen. Microbiol., 72, 269.

MARMUR, J. 1961. A procedure for the isolation of deoxyribonucleic acid from microorganisms. J. Molec. Biol., 3, 208.

RADlOFF, R., BAUER, W., AND Vinograd, J. 1967. A dye-buoyant-density method for the detection and isolation of closed circular duplex DNA: the closed circular DNA in HeLa cells. Proc. Natn. Acad. Sci., U.S.A., 57, 1514.

Richmond, M. H., AND SyKes, R. B. 1973. The $\beta$-lactamases of Gram-negative bacteria and their possible physiological role. Adv. Microbiol. Physiol., 9, edited by A. H. Rose and D. W. Tempest, London and New York, p. 31.

STUDIER, F. W. 1965. Sedimentation studies of the size and shape of DNA. J. Molec. Biol., $11,373$.

Wiedemann, B., Habermann, R., KNothe, H., and Ihrig, L. 1971. Untersuchungen über die Stabilität der Koliflora des gesunden Menschen. 3. Uber das Vorkommen permanenter und passanter Typen bei Kleinkindern. Arch. Hyg. Bakt., 154, 581. 